\title{
Crossed Testicular Ectopia
}

Pediatric Surgery Division of the Department of Surgery, Escola Paulista de Medicina - São Paulo, Brazil.

Crossed testicular ectopia (CTE) is a rare anomaly, characterized by migration of one testis towards the opposite inguinal canal. Presented here is a case of crossed ectopia of the right testis, treated by extraperitoneal transposition of the gonad and right orchiopexy. Embriology and surgical findings suggest that CTE is a common consequence of many unclear ethiologic factors, specially mechanical ones, and can be associated with Muller duct persistence. Review of literature suggests a classification of CTE into 3 types: I associated with inguinal hernia alone; II - associated with persistent mullerian remnants; III - associated with other anomalies without mullerian remnants. Treatment includes transeptal orchiopexy or extraperitoneal transposition of the testis, research for mullerian remnants and other anomalies, and long term postoperative follow-up, due to the risk of becoming malignant.

Uniterms: Cryptorchidism. Ectopic testis. Orchiopexy. Testicular ectopia.

$\mathrm{T}$ lesticular ectopia is an anomaly of testicular descent characterized by localization of the testis out of its normal migration pathway towards the scrotum. There are known five types of testicular ectopia: superficial inguinal (interstitial), femoral (crural), perineal, pubopenile, and crossed.

In crossed testicular ectopia (CTE), the ectopic testis is found in the opposite groin or hemiscrotum, beside the other testis. It is also called transverse testicular ectopia, unilateral double testis, testicular pseudoduplication or transverse aberrant testis. CTE is a very rare congenital anomaly, as there are about 147 reported cases since the first description by Von Lenhossek, 1886.

Presented here is a case of CTE treated by the Pediatric Surgery Division of Escola Paulista de Medicina, and considerations are discussed about new embriological concepts, a morphological classification as well as clinical, physiopathological and therapeutic features.

\section{CASE REPORT}

A 2-year old white boy presented with a swelling in the left groin and empty scrotum at the right side. Physical signs showed left inguino-scrotal hernia with easily reducible content, palpable retractile left testis, and both
Address for correspondence:

Edward Esteves Pereira

Av. Dr. Altino Arantes, 1132 - Ap. 52

Vila Clementino - São Paulo/SP - Brasil - CEP 04042-005 


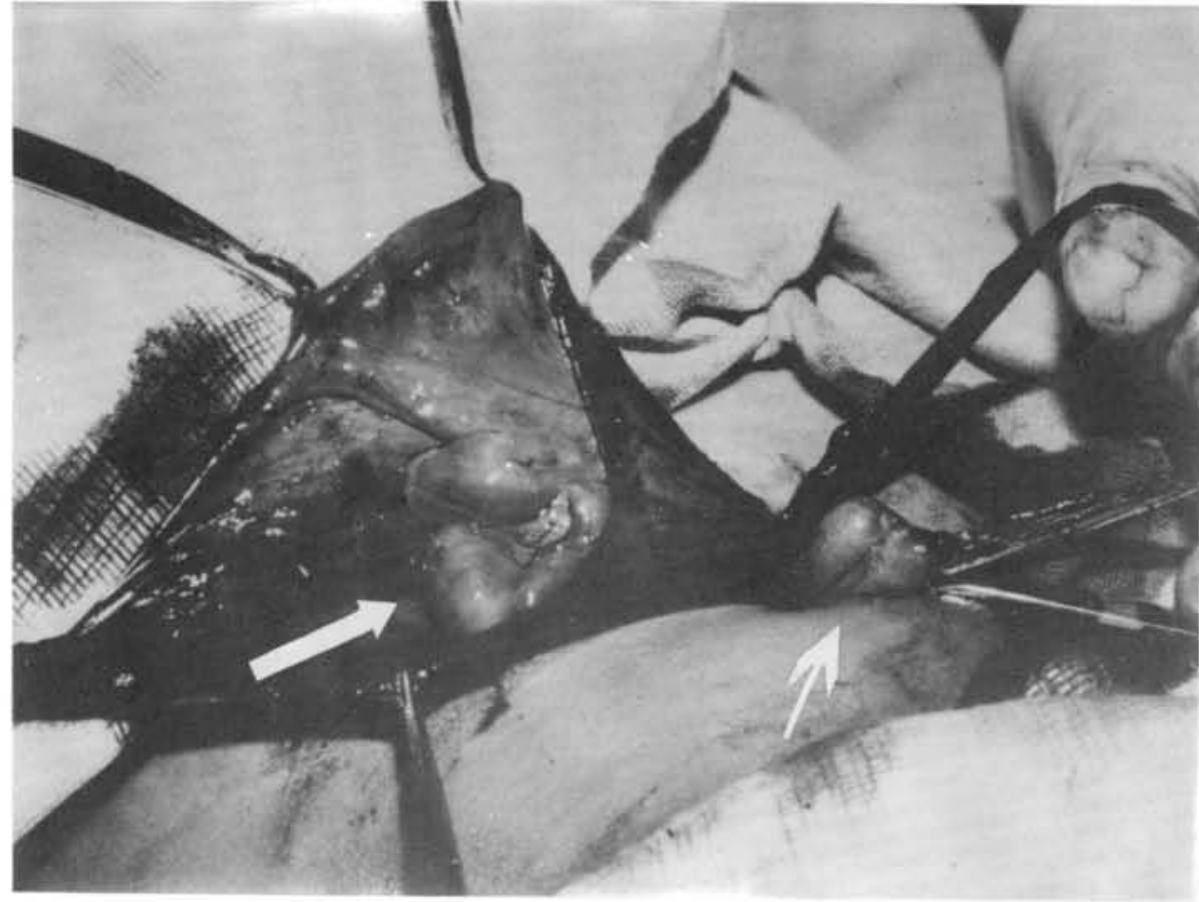

Figure 1 - Left inguinotomy showing left retractile testis (thin arrow) and ectopic right testis inside the hernial sac (thick arrow).

non-palpable right testis and spermatic cord. Suspected of having a left inguinal hernia and right cryptorchidism, he was submitted to surgery. The LEFT inguinotomy revealed two testes of equal appearance within the hernial sac, separated epididymides and vasa deferentia, and the

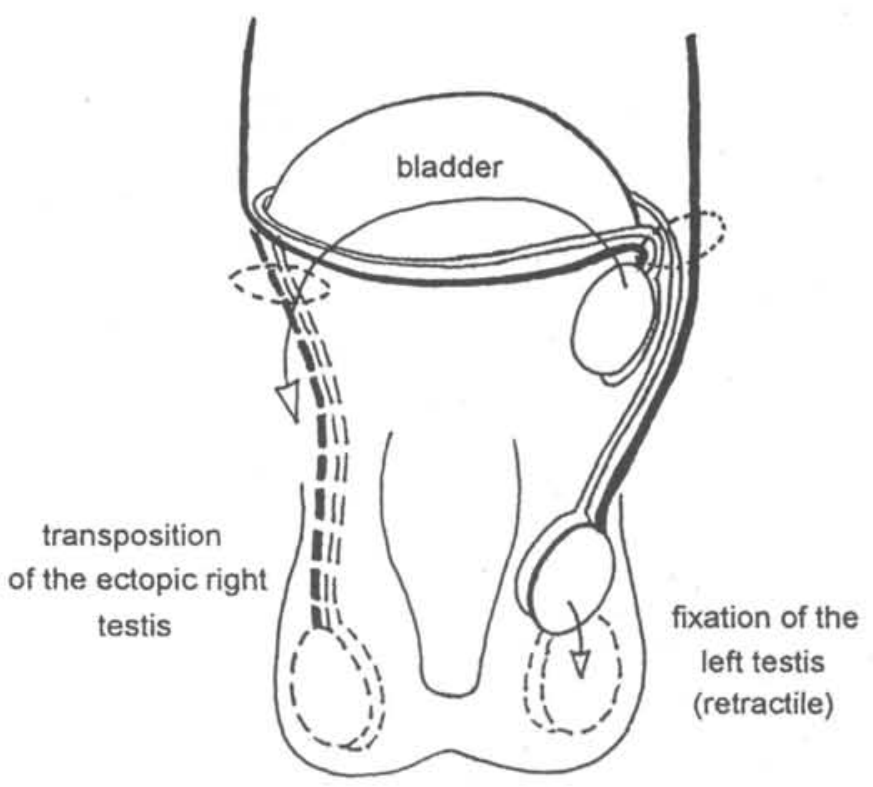

Figure 2 - Scheme showing original positions of the testes (full trace), and final positions after surgery (cut trace). mesorchia was fused by peritoneum just above the internal inguinal ring. The left testis was located in the scrotum but was retractile, and the ectopic right tests lay in the groin, near the left inguinal ring. After isolation and high ligature of the sac, retroperitoneal dissection demonstrated that the LEFT gonad had its vas deferens and blood vessels coming from the left side. The vessels and vas of the RIGHT gonad originated on the right side, crossing the bladder anteriorly until the left inguinal ring, and no gubernaculum was seen attached to the ectopic testis (fig. 1).

The retractile LEFT testis was fixed in the left scrotum pouch. However, after dissection, the spermatic cord of the RIGHT testis was not long enough to allow transeptal orchiopexy without tension. Therefore, it was decided to perform a retroperitoneal transposition of the gonad to the right groin. RIGHT inguinotomy revealed a small external inguinal ring around the ilioinguinal nerve, as well as an empty inguinal canal and an absent internal ring.

The fascia transversalis was opened and retroperitoneal dissection permitted both transposition of the ectopic testis to the right groin and straightening of the cord (fig. 2). Orchipexy to the right scrotal pouch was performed without tension, incisions were closed and convalescence was uneventful. The cariotype analysed posteriorly demonstrated genotype $46 \mathrm{XY}$ and both abdominal ultrasound and intravenous pielography were normal. After three years both testes were palpable in the scrotum.

\section{DISCUSSION}

There are about 147 cases of CTE described since 1886, when Von Lenhossek reported a necropsy finding (28). The largest incidence is found in Europe and Japan. Sixty cases having been published in Japanese literature since the first report in 1912, by Iwasaki(37).

During the last 20 years our service has attended 750 cases of anomalous position of testis, and only one of CTE 
(1:750). After an extensive review of the literature, comparing this index with the data from Campbell (1959) (9), Benson and Lofti (1967) (6), Wooley (1979) (50) and demographic statistics of the United Nations (15), the estimation of global incidence of CTE is about 1:4 million.

There is no statistical difference in regard to the affected side, and over the last 20 years the mean age at diagnosis has been 9.3 years. One case of family incidence was reporded by Stauber, in two brothers with CTE and persistent mullerian remnants (45).

Our child presented a clinical picture analogous to the most frequently found in CTE. The patient usually presents an inguinal hernia with ipsilateral palpable testis and an impalpable testis on the other side. The differential diagnosis includes unilateral anorchia or criptorchidism, or CTE. Occasionally two globular structures are palpable on the hernia side, and preoperative diagnosis may be: a) crossed testicular ectopia; b) cord hydrocele, polyorchidism, spermatocele, epididymitis or testis tumor, splenogonadal fusion or acessory adrenal, all associated with contralateral anorchia or abdominal cryptorchidism.

As surgery is indicated for the hernia, and due to the rarity of CTE and the other associations above, diagnosis is generally made at operation. Preoperative localization of the impalpable testis may be attempted with ultrasound, CT, MNR, and more accurately, with laparoscopy, herniography (46), arteriography or venography. However, if palpation or exams don't identify the testis, surgical exploration will allow diagnosis and treatment.

In all cases where cariotype was analysed, the genotype was $46 \mathrm{XY}$. The most frequent anomalies associated with CTE are inguinal hernia, persistent mullerian remnants and incomplete descent of the nonectopic testis (tab. 1). Although there are only two reported cases (19) of high urinary tract abnormalities (1,2\%), most authors suggest urinary tract evaluation of patients with CTE.

There are some differences among the various cases of CTE, which have produced several theories to explain the genesis of this rare entity $(18,26,28,29,37$.). Many authors propose that abnormal or absent gubernaculum could be important factors, although has been demonstraded normal testes migration after gubernaculum ablation in animal fetuses (14).

Most authors agree that each testis is formed on different sides, and somehow one crosses toward the opposite side in the major part of the migration trajectory. We believe that mechanical causes of CTE, like internal inguinal obstruction (14), absent perotoneum-vaginalis process, absent gubernaculum, mesorchia aderences, and duct or gonads fusion, are certainly relevant factors

\begin{tabular}{lcc}
\hline \multicolumn{3}{c}{$\begin{array}{c}\text { Table 1 } \\
\text { Associated anomalies in 148 cases of CTE } \\
\text { (see references) }\end{array}$} \\
\hline Anomaly & $n$ & $\%$ \\
\hline Inguinal hernia & 145 & 98,0 \\
Persistent Müller duct remanent & 56 & 37,8 \\
Incomplete descent of testis & 12 & 8,1 \\
Hidrocele & 7 & 4,7 \\
Testis tumor & 6 & 4,0 \\
Hypospadia & 6 & 4,0 \\
Absent seminal vesicle & 3 & 2,0 \\
Ectopic seminal vesicle & 1 & 0,6 \\
Ectopic scotum & 1 & 0,6 \\
Supranumerary ectopic epididymis & 1 & 0,6 \\
Bilateral duplication of vasa deferentia & 1 & 0,6 \\
Pieloureteral junction stenosis + & & \\
$\quad$ renal dysgenesis + & 1 & 0,6 \\
$\quad$ seminal vesicle cyst & & \\
Pielic duplication & 1 & 0,6 \\
\hline
\end{tabular}

$(20,24,27,47)$. Our patient, like others, had neither internal inguinal ring nor vaginalis process at the right, and no gubernaculum was attached to the right testis.

Persistent paramenosonephic (Müller's) duct remanent - tubes, rudimentary uterus, hemiuterus occurred in $38 \%$ of CTE cases (Tab.1). Persistence of mullerian remanent in fenotipically normal males represents a recessive trait with male sex restriction $(11,21)$, in chromossome 19 , resulting in abnormal mullerian inhibiting substance (MIS) receptors, or inactive forms of MIS or even inadequate shintesis of MIS, by the fetal testis $(21,38)$. In these cases, the testis would initially aggregate the mullerian remanent and would be carried to the opposite side. Inversely, it is likely that CTE could be the cause, not the consequence, of some cases of Muller's duct remanent. Considering that the ectopic testis has already migrated to the other side before $8-9^{\text {th }}$ week, the period of the Müller duct's sensivity to MIS (25). The concentration of MIS would be insufficient on the original side, leading to non-degeneration of pisilateral mullerian structures. Actually, in most cases the remanent are hemiuterus, tubes or mixed structures associated with an abnormal ectopic testis.

Thevathasan postulated a classification of CTE considering the eventual etiology (47). We suggest a simple classification into three types, based upon the objective presence of associated anomalies, which would imply distinct therapeutic approaches (tab. 2). Many authors 
Table 2

\section{Classification of crossed testicular ectopia (CTE)}

Type I: Simple CTE, associated to inguinal hernia alone

Type II: CTE associated to persistent mullerian remnants

Type III: CTE associated to other anomalies

consider that only cases without persistent müllerian remanent must be termed authentic crossed testicular ectopia $(6,17)$, which would resume the ocurrence to only about 92 cases in the literature.

It's important to assign that thestis tumor in CTE was reported in six cases, including five seminomas in adults with both testes inside the scrotum $(19,31,37$.). Therefore long term follow-up and wise orientation should be accomplished to all patients.

\section{TREATMENT}

In the evidence of CTE at the operation, the approach depends on the operatory findings:

Type I (CTE with inguinal hernia only):

a) Dissection and high ligature of the hernia sac.

b) Dissection and isolation of both cords and vas deferens may be performed, allowing mesorchia separation and appraisal of both testes origin, in order to exclude polyorchidism. c) Orchiopexy. If spermatic cord lenght is good, as in most cases, it's recommended to fix the ectopic testis in the opposed scrotal pouch by TRANSEPTAL technique (Ombrèdanne-Miller) (36). If the spermatic cord is short, as in our case, one can perform testis TRANSPOSITION to the other groin through contralateral inguinotomy, with or without laparotomy, by intra or extraperotoneal approach, or by staged orchiopexy.

d) Contralateral inguinal exploration is important to rule out polyorchidism and may provide ectopic testis transposition in cases of short spermatic cord.

e) Intraoperative vasography is suggested by Fujita (19) and Peterson (41), in order to evaluate anatomy, exclude polyorchidism, and eventually avoid unnecessary laparotomy or contralateral inguinotomy. We consider vasography difficult and dangerous to the fine vas of a child.

f) It the testis is noted to be atrophic of if CTE occurs after puberty, orchiectomy is indicated due the high risk of malignization (4\%).

Type II (CTE associated with mullerian remnants): besides the steps quited above, in the presence of mullerian remnants, their ablation is not obligatory, and just a segmentary ressection may be done to provide pathological study. The inferior uterine segment is often adhered to the vas deferens and must be preserved to avoid iatrogenic infertility $(18,21,33)$.

Type III (CTE associated with different other abnomalities): In the evidence of other anomalies, treatment should be appropriate to each case.

Genetic evaluation shall be performed methodically. Despite association of $1,2 \%$ of high urinary tract anomalies, it's recommended urographic investigation in all cases of crossed testicular ectopia.

\section{Resumo}

Introdução: A ectopia testicular cruzada (ETC) é uma anomalia rara, caracterizada pela descida de um testítulo no canal inguinal do lado oposto. Apresentamos um caso de ectopia cruzada do testículo direito, tratado por transposição extraperitoneal da gônada e orquipexia direita. Conclusāo: Os conhecimentos embriológicos e os achados cirúrgicos sugerem que a ETC seja uma consequeência comum de vários fatores etiológicos, sobretudo fatores mecânicos, e pode causar persistência do ducto de Müller. Após extensa revisāo da literatura,sugerimos uma classificação da ETC em 3 tipos: 1 -associada somente à hérnia inguinal; II associada a remanescentes mullerianos; III - associada a outras anomalias, sem remanescentes mullerianos. O tratamento inclui orquipexia trans-septal ou transposição trans-abdominal do testículo, pesquisa de remanescentes mullerianos e outras anomalias, e seguimento pós-operatório a longo prazo, devido a risco de malignizaçăo. 


\section{REFERENCES}

1. AHAD, A.; WANI, N.A.; BHAN, L.; GARYALI, R.K. Ectopia testis transversa. Brit J Urol, 50: 215, 1978.

2. AHMED, S. - A case of transverse testicular ectopia. J Urol, 106: 308-309, 1971.

3. APPLEBY, B. - Pseudo-duplication of testis. Med J Austr, 2:215, 1961.

4. BANKS, A.G. - A case of transverse ectopia of the testis. Brit Med J, 2: 589, 1926.

5. BEASLEY, S.W.; AULDIST, A.W. - Crossed testicular ectopia in association with double incomplete testicular descent. Austr N Z Surg, 55: 301-303, 1985.

6. BENSON, D.D.; LOFTI, M.W. - The pouch technique in the surgical correction of cryptorchidism in infants and children. Surgery, 62: 967, 1967.

7. BRITO, M.A.; LANNA, J.C.B.D.; PAIXĀO, R.M.; SOBRINHO, J.M.D.L. - Ectopia testicular transversa. Rev Ass Med Bras, 27: 275-276, 1981.

8. BROWNE, A.F.; BLACK, N. - Unilateral double testicles on transverse ectopia of the testis. Can Med Ass J, 82: 84$85,1960$.

9. CAMPBELL, H.E. - The incidence of malignant growth of the undescended testicle: a reply and re-evaluation. J Urol, 81: 663,959 .

10. CARRAGHER, A.M.; BOSTON, V.E. - Mullerian inhibiting factor deficiency syndrome with crossed testicular ectopia. Brit J Urol, 60: 275-276, 1987.

11. COHEN-HAGUENAUER, O.; PICARD, J.Y.; MATTÉR, M.G. - Mapping of the gene of anti-mullerian hormone to the short arm of the chromossome 19. Cytogenet Cell Genet, 44: 2-6, 1987.

12. CORRÊA, M.A.G.; FEDERICI, J.R.D.; NOÉ, A.J.; CANELLAS, E.B.; GOMES, P.M.B.; BIZZO, E.F.S.; SOUZA, T.A.; VIEIRA, H.J.; SABANEEF, J.; BRINGEL, P.J.P. - Ectopia testicular cruzada - relato de um caso. J Bras Urol, 9: 115-116, 1983.

13. DAJANI, A.M. - Transverse ectopia of the testis. Brit J Urol, 41: 80-82, 1969.

14. DAVIS, J.E. - Transverse aberrant testicular maldescent. US Armed Forces Med J, 8: 1046-1050, 1957.

15. Demographic Yearbook, 42th ed. New York, United Nations, 25-200, 1993.

16. DICKINSON, A.J.; HEWETT, P. - Transverse testicular ectopia presenting as strangulated inguinal hernia. Brit J Urol, 66: 217, 1990.

17. DOGRUYOL, H.; ÖZCAN, M.; BALKAN, E. - Two rare genital abnormalities: crossed testicular and scrot-testicular ectopia. Brit J Urol, 70: 201-203, 1992.

18. FOURCROY, J.L.; BELMAN, A.B. - Transverse testicular ectopia with persistent mullerian duct. Urology, 19: 536538, 1982.

19. FUJTA, J. - Transverse testicular ectopia. Urology, 16: 400402, 1980.

20. GAUDERER, M.W.L.; GRISONI. E.R.; STELLATO, T.A.; PONSKY, J.L.; IZANT Jr, R.J. - Transverse testicular ectopia. J Ped Surg, 17: 43-47, 1982.
21. GAUTIER-BENOIT, C.; BUGNON, P.Y.; SERVAIS, B.; JEAN. P. - Le syndrome d'ectopie testiculaire transverse avec persistance de vestiges mulleriens ou la bourse viede et le cordon trop plein. J Chir (Paris), 127: 286-289, 1990.

22. GIANNOPOULOS, A.; PANTAZOPOULOS, D, MICHALOPOULOS, A.; GOULANDRIS, N.; DIMOPOULOS, C. - Association d'une forme rare d'ectopie testiculaire, d'un epididyme ectopique surnumemráire. Ann d'Urol, 20: 267-270, 1986.

23. GOLLADAY, E.S.; REDMAN, J.F. - Transverse testicular ectopia. Urology, 19: 181-186, 1982.

24. GRAPIN, C.; GERAUD, M.; AUDRY, G. - Mecanisme de la non descent testiculaire. Chir Ped, 30: 14-137, 1989.

25. GRUMBACH, M.M.; CONTE, F.A. - Disorders of sexual differentiation. In Wilson, J.D.; Foster, D.W. - Williams: Textbook of Endocrinology. Philadelphia, WB Saunders Co., 383-493, 1985.

26. GUPTA, R.L.; DAS, P. - Ectopia testis transversa. J Ind Med Ass, 35: 547-549, 1960.

27. HAMMOUNDI, S. - Transverse testicular ectopia. J Ped Surg, 24: 223-224, 1989.

28. HALSTEAD, A.E. - Ectopia testis transversa. Surg Gynecol Obstet, 4: 129-132, 1907.

29. HERTZLER, A.E. - Ectopia testis transversa with infantile uterus. Surg Gynecol Obstet, 23: 597-601, 1916

30. KHANESRAM H,L.; GUPTA, A.S.; MALPANI, N.K. Transverse testicular ectopia. Brit J Urol, 50: 283, 1978.

31. LOWSLEY, O.S.; PORRAS, E. - Congenital anomalies of the testicle. J Int Coll Surg, 15: 332-342, 1951.

32. MACKENZIE, D.W. - Pseudohermaphrodismus masculinus internus. Surg Gynecol Obstet, 34: 51, 1922.

33. MAFOUZ, E.H.; ISSA, M.A.; FARAG, T.I.; NAGUIB, K.K.; AL-AWAS, S.A.; SCHIMKE, R.N. - Persistent mullerian duct syndrome: report of two boys with associated crossed testicular ectopia. J Ped Surg, 25: 692-693, 1990.

34. MARSH, F. - Two testicles on one side. Brit Med J, 2: 1354, 1911.

35. MARTIN, E.L.; BENNETT, A.H.; CROMIE, W.J. Persistent müllerian duct syndrome with transverse testicular ectopia and spermatogenesis. J Urol, 147: 1615-1617, 1922.

36. MILLER, H.C. - Transeptal orchiopexy for cryptorchism. J Urol, 98: 503-505, 1967.

37. MIURA, T.; TAKAHASHI, G. - Crossed ectopic testis with common vas deferens. J Urol, 1324: 1206-1208, 1985.

38. MOULI, K.; McCARTHY, P.; RAY, P.; RAY, V.; ROSENTHAL, I.R. - Persistent mullerian duct syndrome in a man with transverse testicular ectopia. J Urol, 139: 373 $375,1988$.

39. MUKERJEE, S.; AMESUR, N.R. - Transverse testicular ectopia with unilateral blood suply. Ind J Surg, 27: 547$550,1965$.

40. PAVÃO, J.M.; GONZAGA, R.F.; CARDOSO, J.A.G.; FERREIRA, A. - Transverse testicular ectopia corrected by a modified Ombrédanne operation. J Urol, 132: 1194, 1984.

41. PETERSON, N.E. - Association of transverse testicular ectopia and seminal vesicle cyst. J Urol, 188: 345-346, 1977. 
42. RAO, B.K.; KAPUR, M.M. - Transverse testicular ectopia: a case report. J Urol, 124: 149-150, 1980.

43. SASTRY, S.C.; VENKATESWARLU, K.; HUSSAIN, B.A. - Transverse testicular ectopia. Int Surg, 59: 373-374, 1974.

44. SINGLA, S.L.; MARYA, S.K.S.; KUMAR, B. - Transverse testicular ectopia. Ind Pediat, 24: 1148-1149, 1987.

45. STAUBER, R. - The familial incidence of transverse testicular dystopia. Zentralbl Chir, 90: 6210625, 1965.

46. SWANK, R.L.; AFSHANI, E. - Transverse testicular ectopia: preoperative diagnosis. J Ped Surg, 9: 425, 1974.
47. THEVATHASAN, C.G. - Transverse ectopia of the testis. Austr N Z J Surg, 37: 93-102, 1967.

48. TILAK, G.H.; TALWALKAR, M.G. - A case of ectopic testis transversa. Brit J Urol, 34: 227-228, 1962.

49. TOLETE-VELCEK, F.; BERNSTEIN, M.O.; HANSBROUGH, F. - Crossed testicular ectopia with bilateral duplication of the vasa deferentia: an unusual finding in cryptorchism. J Ped Surg, 23: 641-643, 1988.

50. WOOLEY, M.M. - Cryptorchidism. In Ravitch, M.M.; Welsh, K.J.; Benson, C.D. et al. - Pediatric Surgery. Chicago. Chicago Year Book Medical Publishers, 1979. 